\title{
Green Foot Syndrome
}

"María Rogel-Vence, Lucía González-Ruiz, Marcos Carmona-Rodríguez, Juan Luis Santiago-SM

متالازمة القدم الخضضراء

ماريا روجيل فينس، لوسيا غونزاليز-رويز، ماركوس كارمونا-رودريغيز، خوان لويس سانتياغو

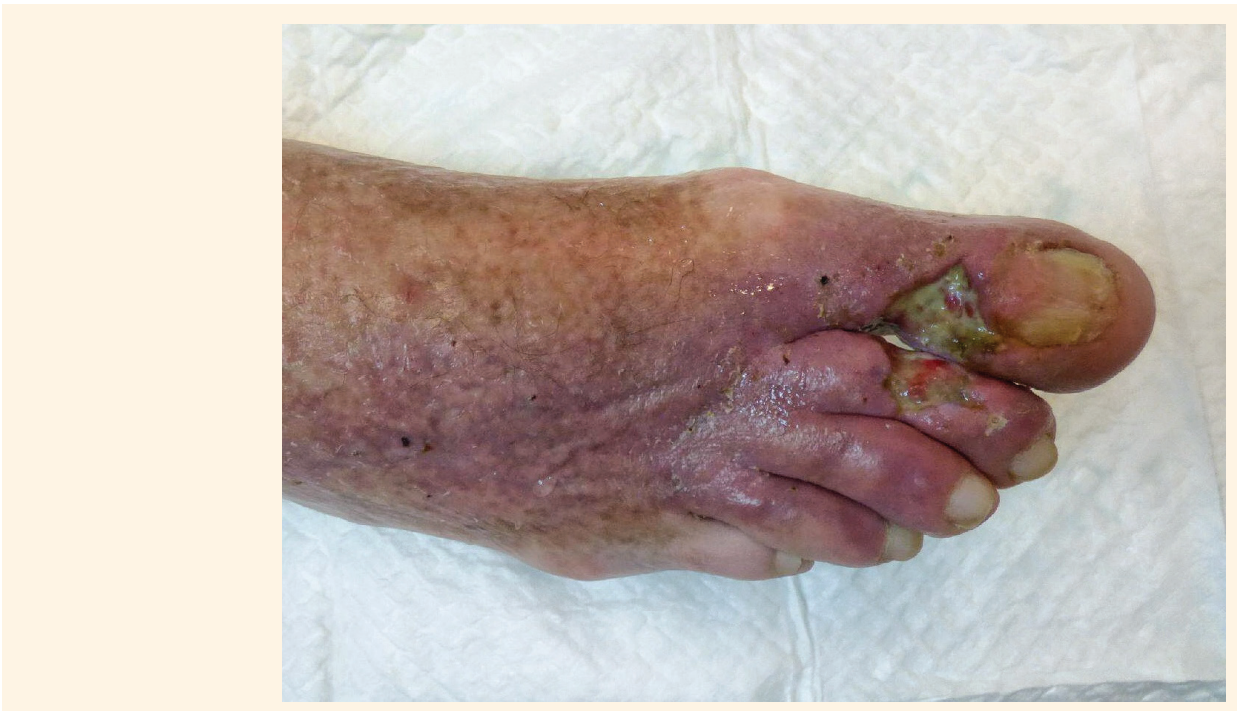

Figure 1: Photograph of the right foot of a 51-year-old male prisoner showing two mirror-image ulcers with irregular margins and yellow-greenish discolouration surrounding the first interdigital space.

\section{A}

51-YEAR-OLD MALE PRISONER PRESENTED TO the Department of Dermatology, Hospital General Universitario de Ciudad Real, Cuidad Real, Spain, in 2018. He had painful ulcers on the right foot with a foul odour, a burning sensation and pruritic eczematous lesions on both feet for the past five years. The ulcers showed intermittent course and worsened during warmer months. He had a history of ischaemic cardiomyopathy, chronic hepatitis due to hepatitis $\mathrm{C}$ and a past hepatitis $\mathrm{B}$ infection. The patient had no personal or familial history of immunosuppressive diseases. He stated that he used to wear closed and tight shoes and there was no specific foot care or foot hygiene in prison. Physical examination revealed two mirror-image ulcers with irregular margins and yellow-greenish discolouration surrounding the first interdigital space on the right foot [Figure 1]. Maceration areas were in all interdigital spaces of both feet, while a pruritic eczematous eruption was affecting the dorsum of the right foot [Figure 2]. The patient's white blood cell count, serum C-reactive protein level, cryoglobulin level, antineutrophil cytoplasmic antibody level, antinuclear antibody level and coagulation profile were normal. An X-ray of the right foot was unremarkable. Skin biopsies showed chronic granulation tissue without visualising any pathogens using Ziehl-Neelsen and periodic acid-Schiff staining. Direct examination under light microscopy of a potassium hydroxide preparation did not show any fungal hyphae or spores. Cultures of cutaneous ulcers grew bacteria that were identified as Pseudomonas aeruginosa. These results were confirmed by two consecutive cultures taken from skin biopsies, which also excluded mycobacteria and fungal infection. An antibiogram showed resistance to gentamycin and susceptibility to both ciprofloxacin and levofloxacin. In light of the clinical findings, results of the cultures and the antibiogram, the patient was given oral ciprofloxacin (500 mg) twice daily for 10 days. He was instructed to keep his feet dry and place gauze between the digits after cleaning the ulcers with povidoneiodine solution. In addition, the patient was instructed 


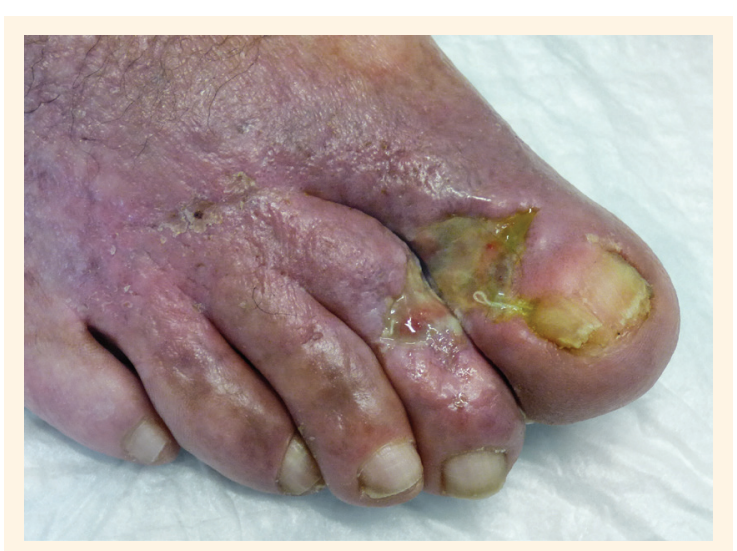

Figure 2: Photograph of the right foot of a 51-year-old male prisoner showing cutaneous maceration of the first interdigital space and eczematous skin on the dorsum.

to use a topical solution of $1 / 1000$ zinc sulphate in order to take advantage of its astringent effect. Two weeks after starting the oral ciprofloxacin, the ulcers had improved and did not have a foul odor or greenish discolouration and the burning and painful sensation had dissipated. The patient provided informed consent to report his case for scientific purpose.

\section{Comment}

P. aeruginosa is a gram-negative bacillus, which may infect the skin or deeper tissues. Excessive moisture and occlusive conditions are necessary for colonisation of this bacterium and the resulting clinical manifestations. ${ }^{1}$ Green foot syndrome (GFS) is an uncommon cutaneous disease caused by $P$. aeruginosa and is frequently associated with poor hygiene, humidity and immunosuppression. ${ }^{2}$ Trench foot syndrome (TFS) is a related condition, common in military personnel, but is characterised by an acute onset and more aggressive course if not treated appropriately. ${ }^{3}$ On the other hand, GFS is less aggressive and has a chronic evolution. In GFS, chronic painful ulcers develop on the feet as a result of a $P$. aeruginosa infection, which can penetrate at sites of maceration, particularly, if there is dermatophytic infection in the foot. ${ }^{1}$ As in other cutaneous infections by this bacterium, a characteristic yellow-greenish colour is seen in these ulcers. ${ }^{4}$ When deep infection is suspected (i.e. painful sensation, fever, chills, etc.), antibiotic treatment should be administrated combined with topical solutions.

The current patient developed a chronic skin disease consisting in painful ulcers on the dorsum of the right foot, with intermittent course, for five years. While he did not have a medical history suggestive of immunosuppressive disease and excluding any previous history of parenteral drug abuse, he did use closed and tight shoes where poor hygiene and excessive sweating facilitated the rapid growth of $P$. aeruginosa which most likely led to GFS.

\section{References}

1. Lee SH, Cho SB. Cast-related green foot syndrome. Clin Exp Dermatol 2009; 34:364-5. https://doi.org/10.1111/j.1365-2230. 2009.03317.x.

2. Bae JM, Park YM. Green foot syndrome: A case series of 14 patients from an armed forces hospital. J Am Acad Dermatol 2013; 69:198-9. https://doi.org/10.1016/j.jaad.2013.05.012.

3. Anand P, Privitera R, Yiangou Y, Donatien P, Birch R, Misra P. Trench foot or non-freezing cold injury as a painful vasoneuropathy: Clinical and skin biopsy assessments. Front Neurol 2017; 8:514. https://doi.org/10.3389/fneur.2017.00514.

4. García-Martínez FJ, López-Martín I, Castellanos-González M, Segurado-Rodríguez MA. Úlceras plantares verdes. Enferm Infec Microbiol Clin 2017; 35:536-7. https://doi.org/10.1016/j. eimc.2015.10.010. 